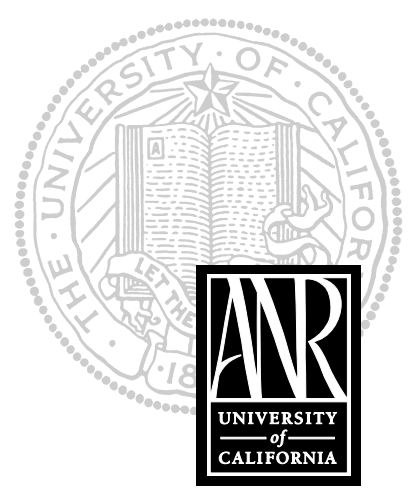

UNIVERSITY OF CALIFORNIA

Division of Agriculture and Natural Resources

http://anrcatalog.ucdavis.edu

\title{
Rhubarb Production in
}

California

WAYNE L. SCHRADER, University of California Cooperative Extension Vegetable Farm Advisor, San Diego County

\section{INTRODUCTION}

Rhubarb and pieplant are common names for Rheum rhabarbarum L. It is a member of the buckwheat family and has large, thick, succulent petioles (stalks) that are used as food. Rhubarb grows wild in central Asia. It was cultivated over 2,000 years ago for its medicinal properties (the dried root is a strong purgative). Rhubarb was introduced into Britain in the sixteenth century and became a food crop in North America in the eighteenth century. Rhubarb's unique taste makes it a favorite ingredient in pies and desserts. It is low in calories but a good source of vitamins A and C, thiamin, riboflavin, niacin, potassium, phosphorous, and high quality dietary fiber. It is currently cultivated in much of Europe and the United States. Fresh rhubarb is available from early winter through early summer. Winter rhubarb is commercially produced in forcing houses in the northern United States and Canada.

In the United States, commercial production (about 1,200 acres) is concentrated in Washington, Oregon, and Michigan. Small commercial acreage is found in many northern states. Hothouse rhubarb (about 175 acres) is produced in Washington and Michigan. Excellent commercial yields range from 15 to 18 tons per acre (34-41 t/ha). Average commercial yields are 10 tons per acre ( $23 \mathrm{t} / \mathrm{ha})$. Red varieties yield 50 percent less than green types. Only red varieties are commercially important. Perennial fields can remain productive for 8 to 15 years. Yields, however, may decline after 4 or 5 years due to crowding.

\section{PERENNIAL RHUBARB PRODUCTION}

Rhubarb is a hardy, cool-season perennial that is relatively resistant to frost. It is normally propagated from crowns that consist of woody and fleshy rhizomes, a fibrous root system, and buds. Healthy, vigorous, 3- to 4-year-old crowns are divided to obtain two or more buds per propagation piece. Crowns that are 5 to 6 years old yield 8 to 10 good quality propagation pieces. Rhubarb seed is not used to establish commercial production fields because seeded varieties lack the uniformity of color and petiole size necessary for commercial production.

Crown pieces should be planted 3 to 6 inches $(8-15 \mathrm{~cm})$ below the surface of the soil. The most common spacing for hand-harvested rhubarb is 2-by-6-feet $(3,600$ plants per acre $[8,892$ plants/ha]). Rhubarb intended for mechanical harvesting is planted with an in-row spacing of 18 inches $(46 \mathrm{~cm})$ and rows 4 feet $(1 \mathrm{~m})$ apart (7,200 plants per acre [17,784 plants/ha]). Wilde Manufacturing Co. of Bailey, Michigan, has developed a machine for mechanical harvesting.

Cultivation for weed control should start early and should be shallow to avoid root damage. During the first year after planting, the field should not be harvested since the leaves are needed to nourish the roots for the next year's growth. One light picking may be taken during the first year if the plants are vigorous. Rhubarb crowns are normally planted in the early spring. Disease and insect pest pressures, however, may require more frequent field replanting. 
Following one season of growth, the rhubarb crown becomes dormant. Temperatures below $40^{\circ} \mathrm{F}\left(4.4^{\circ} \mathrm{C}\right)$ are required to stimulate bud break and subsequent regrowth. The first shoots that appear in the spring are edible petioles with inedible leaves (leaves are poisonous). These emerge sequentially as long as temperatures remain cool (below $90^{\circ} \mathrm{F}\left[32.2^{\circ} \mathrm{C}\right]$ ). Spring temperatures that average $75^{\circ} \mathrm{F}$ $\left(23.9^{\circ} \mathrm{C}\right)$ during the day and $50^{\circ}$ to $55^{\circ} \mathrm{F}\left(10^{\circ}\right.$ to $\left.12.8^{\circ} \mathrm{C}\right)$ at night are optimal for rapid vegetative growth. When average summer temperatures rise above $90^{\circ} \mathrm{F}$ $\left(32.2^{\circ} \mathrm{C}\right)$, top growth is suppressed and plants become dormant. When temperatures decline in the fall, foliage growth resumes.

Obtain planting stocks from reputable nurseries as much as possible. When planting stock is obtained from old fields, care should be taken to ensure that crowns are disease free. Crowns can be dug in the late fall, late winter, or early spring and stored in a cool place. Plant crown divisions in the early spring (February to April) as soon as soil conditions permit planting. Lower temperatures during spring and early summer favor the development of more red color. At higher temperatures green coloration is more pronounced.

Perennial rhubarb production is generally not successful in tropical and subtropical southern latitudes of the United States unless winter temperatures fall below $40^{\circ} \mathrm{F}\left(4.4^{\circ} \mathrm{C}\right)$. Rhubarb can be produced in southern states at altitudes that have adequate freezing weather in the winter months.

\section{ANNUAL RHUBARB PRODUCTION}

In southern areas where freezing weather rarely occurs, rhubarb can be grown as an annual. But if grown during hot weather, annual rhubarb either dies or produces thin and spindly leaf stalks that lack color. Rhubarb can be grown as an annual in subtropical and tropical climates that have a cool production period. In these warmer climates rhubarb is grown as an annual from seed. Rhubarb seed can be purchased by mail order. Seed are encased in a large, paper-like shell. Soak the seed in water for a few hours before planting in sterilized planting mix. Rhubarb seeds can be planted in peat pots or transplant trays about $1 / 4$ inch $(1 / 2 \mathrm{~cm})$ deep. Seedlings should be protected from intense sunlight early in their growth.

Transplants are moved to the field when they are 3 to 4 inches $(8-10 \mathrm{~cm})$ in height and after being appropriately acclimated to outside temperatures and light (hardened off). Because plants grown from seed are not true to parental type, there will be a mixture of plant colors ranging from green to pink with red or partly red stems. Plants rarely form flowers at high temperatures and short day-lengths, but any flower heads that do develop should be removed unless you are saving seed. Rhubarb grown at higher temperatures tends to have fewer stems with intense red color. Harvest stalks as they mature. Annual rhubarb growers in Florida report that they have achieved good yields by planting seed in August and harvesting March through May. The variety Victoria is reported to be very productive in annual production.

\section{SOIL}

Rhubarb prefers fertile, well-drained soils that are high in organic matter with a $\mathrm{pH}$ of 6.0 to 7.0. Rhubarb is tolerant of soil acidity and prefers slightly acid soils. Maximum yields are obtained with soils at a pH of 6.0 to 6.8. Liming should be done if $\mathrm{pH}$ is below 5.6. Lighter soils will produce an earlier crop but require more irrigation and fertilization. Prior to planting, fields should be plowed deeply and 
worked in the fall or spring. Fifteen tons of composted manure per acre should be applied to fields before planting. Choose fields free of problem perennial weeds. A clean planting site is essential for the cultivation of rhubarb since no herbicides are registered for use on this crop. Perennial weeds should be eliminated from the planned rhubarb area the year before planting. Fields should be cultivated in the spring and after cutting. Hand-hoeing may be necessary to remove weeds that are close to the plants.

\section{FERTILIZATION}

A soil test is the most accurate way to determine fertilizer requirements. Composted manure at 15 to 30 tons per acre (34-68 t/ha) may be applied in the fall or as early as possible in the spring. In addition, table 1 shows recommended application rates of nitrogen, phosphate, and potash.

Nitrogen fertilizer applications should be split into three or more sidedress applications (before growth starts in the spring, after growth starts, and after harvest) or applied through drip irrigation systems weekly. Rates of application should be reduced to reflect amounts of nutrients that are shown to be available in the soil through soil testing. Nitrogen rates may be reduced in the first 2 years with manure applications.

If boron is needed, a foliar application of $0.5 \mathrm{lb}$ per acre $(0.56 \mathrm{~kg} / \mathrm{ha})$ may be made in early spring when plants are 6 to 8 inches $(15-20 \mathrm{~cm})$ tall.

\section{IRRIG AT I O N}

Maintain adequate soil moisture after the harvest season to ensure good regrowth. A second crop may be harvested in early to mid July (weather permitting), after which the field may be regrown and allowed to go dormant through late July and August. If harvested in July, growth will be delayed the following spring. Soil type does not affect the amount of total water needed, but does dictate frequency of water application. Lighter soils need more frequent water applications, but less water applied per application.

Table 1. Fertilizer recommendations

\begin{tabular}{lcc}
\hline & $\begin{array}{c}\text { In year of initial } \\
\text { planting (Ib/acre) }\end{array}$ & $\begin{array}{c}\text { In subsequent } \\
\text { years (Ib/acre) }\end{array}$ \\
\hline Nitrogen $(\mathrm{N})$ & $70-80$ & $140-160$ \\
Phosphate $\left(\mathrm{P}_{2} \mathrm{O}_{5}\right)$ & $70-80$ & $70-80$ \\
Potash $\left(\mathrm{K}_{2} \mathrm{O}\right)$ & $140-160$ & $140-160$ \\
\hline
\end{tabular}

Source: Anonymous 2000

\section{GROWTH ENHANCEMENT}

Rhubarb requires a period of temperatures below $40^{\circ} \mathrm{F}\left(4.4^{\circ} \mathrm{C}\right)$ to break dormancy and stimulate the production of leaf petioles. When temperatures exceed $45^{\circ}$ to $50^{\circ} \mathrm{F}$ $\left(7.2^{\circ}\right.$ to $\left.10.0^{\circ} \mathrm{C}\right)$, crown buds begin to develop. Gibberellic acid (if gibberellic acid is registered for use on rhubarb in your area) can be used to substitute for part of the cold units required to break dormancy. Early growth may be enhanced 10 days to 2 weeks by the use of clear plastic row covers that may be applied in early February. Allow sufficient slack in the cover for stalk growth. Gibberellic acid may also be injected into the crowns at 0.01 gram of gibberellic acid (Pro-Gibb) per crown. 
Injection is normally accomplished using a pneumatic, hand-operated injector wand that delivers the correct dosage when it is pushed into the rhubarb crown.

\section{VARIETIES}

Red Types. The Crimson variety is also known as Crimson Cherry, Crimson Red, and Crimson Wine. Crimson produces brightly colored red stalks with the unique characteristic of being red throughout under normal temperature and moisture conditions. Other vigorous red varieties are Valentine, Canada Red, and Cherry Red. Cherry Red is grown in California and produces long, thick, deep-red stalks.

Speckled Types (pink). Victoria produces large stalks of excellent quality. It is long and round with smooth ribs. It develops pink speckling on a light green stalk. The pink color is more intense at the bottom of the stalk, fading to a solid green near the top. Victoria is commonly used for forcing. Strawberry is very similar to Victoria and, in fact, may be the same variety. MacDonald is another pink type that produces well. German Wine is similar to Victoria but is more vigorous and more intense in color, typically with a darker pink speckling on a green stalk.

Green Types. Riverside Giant is a cold-hardy, vigorous producer with large-diameter, long, green stalks.

Limited quantities of crown planting stock may be available from West Union Gardens, 7775 NW Cornelius Pass Rd., Hillsboro, OR 97124; Territorial Seed Co., P.O. Box 157, Cottage Grove, OR 97424-0061; or Burpee Seed Company, 300 Park Avenue, Warminster, PA 18991-0001.

\section{HARVESTING, HANDLING, AND STORAGE}

Harvest stalks as they mature. For processing, both ends of the petiole are trimmed so that no leaf tissue remains. For the fresh market, 1/4 inch of leaf tissue is usually left attached to the petiole, and the basal end is not trimmed. If the entire leaf section is removed, more severe splitting of the petiole can occur.

At the end of petiole harvest, new shoots will emerge. These provide the reserves for the following year's crop. If growth and moisture reserves are adequate, a second harvest may be made in the fall, but stalks must be firm and not pithy. Do not use stalks that have been frozen or that are limp. Freeze-damaged stalks may contain high levels of the poisonous oxalic acid that has migrated from the leaf blades.

Stalks should not be harvested during the first year of growth in perennial fields. Stalk color is best after the field is 2 to 3 years old. In subsequent years, harvesting can be expected to start in early spring and end in early summer, depending on local weather conditions. This will vary with management practices, variety, climatic conditions, and market demand. Plants should never be over-harvested. A certain amount of foliage needs to be left on the plant for the development of the present crop as well as the following year's crop.

Rhubarb is commonly packaged in 20-pound (9-kg) cartons or in 1-pound (1/2$\mathrm{kg}$ ) film bags in cartons of 10 bags each. Stalks should be cooled rapidly after picking to prevent wilting. Rhubarb is stored at $32^{\circ} \mathrm{F}\left(0^{\circ} \mathrm{C}\right)$ and 95 to 100 percent relative humidity. Fresh rhubarb stalks in good condition can be stored for 2 to 4 weeks. It can be hydrocooled or forced-air cooled. The temperature of the stalks should reach $32^{\circ}$ or $33^{\circ} \mathrm{F}\left(0^{\circ}\right.$ or $\left.0.6^{\circ} \mathrm{C}\right)$ within 1 day of harvest. Boxes of stalks should be stacked to allow ample air circulation. Poor air circulation leads to product heating and mold 
growth. Fresh rhubarb cut into 1-inch pieces and packaged in 1-lb perforated polyethylene bags can be stored 2 to 3 weeks at $32^{\circ} \mathrm{F}\left(0^{\circ} \mathrm{C}\right)$ at high relative humidity.

\section{INSECT PESTS AND DISEASES}

Rhubarb is a hardy perennial that is not usually seriously affected by insect pests. It is occasionally attacked by Japanese beetle (Popillia japonica), potato flea beetle (Epitrix cucumeris), stalk borer (Papaipema nebris), European corn borer (Pyrausta nubilalis), potato leafhopper (Empoasca fabae), armyworms (Spodoptera spp.), cutworms (various species), garden symphylan (Scutigerella immaculata), and gray garden slugs (Agriolimax reticulatum). Proper rotations and field selection can help to minimize problems with insects.

Rhubarb is subject to fungal attack from species of Phytophthora, Pythium, Rhizoctonia, and Botrytis. Root rot is common in rhubarb fields that are poorly drained or over watered. Ramularia leaf spot may cause angular spots on the leaves.

\section{COOKING AND NUTRITION}

Rhubarb is processed by cooking, canning, and freezing. Its acidic taste is due to oxalic acid. Adding sugar softens the acidic flavor. Rhubarb contains pro-vitamin A and vitamin $C$.

WARNING: Rhubarb leaves are poisonous because they contain oxalates. People have died trying to use the leaves as a vegetable green. Eat only the petioles (stalks). Trim off all leaf tissue before using rhubarb in recipes.

There are hundreds of recipes for rhubarb breads, crisps, cobblers, pies, tarts, teas, and wines in cookbooks and on the Internet. One recipe is included here for the sake of completeness.

\section{RHUBARB COBBLER}

\section{Ingredients}

Rhubarb Filling

$3 / 4$ to 1 cup white sugar

2 tablespoons cornstarch

4 cups sliced rhubarb

1 tablespoon water

butter

ground cinnamon

\author{
Topping \\ 1 cup all-purpose flour \\ 1 tablespoon white sugar \\ $1_{1 / 2}^{1 / 2}$ teaspoons baking powder \\ $1 / 4$ teaspoon salt \\ $1 / 4$ cup butter \\ $1 / 4$ cup milk \\ 1 egg, beaten
}

\section{Directions}

Filling: Place rhubarb and water in a medium saucepan. Mix sugar and cornstarch together and then stir into rhubarb and water. Bring to a boil. Cook and stir for 1 minute. Pour rhubarb mixture into a greased 13-by-9-inch pan. Dot with butter. Sprinkle with cinnamon.

Topping: In a medium bowl, sift together flour, sugar, baking powder, and salt. Cut in butter until it becomes coarse crumbs. In a separate bowl, mix together milk and egg. Pour milk and egg mixture, all at once, into dry ingredients, stirring just to moisten. Drop by teaspoon on top of hot rhubarb. Sprinkle with sugar. Bake for 20 minutes at $400^{\circ} \mathrm{F}\left(205^{\circ} \mathrm{C}\right)$. 


\section{B I B LI O G R A P H Y}

Advisory Committee on Vegetable Crops. 1997. Rhubarb. In Vegetable crops production guide for the Atlantic provinces. Halifax, Nova Scotia: Atlantic Provinces Agriculture Services Co-ordinating Committee.

http://agri.gov.ns.ca/pt/hort/vegetables/guides/rhubarb.htm

Anonymous. 2000. Rhubarb, Rheum rhabarbarum. In Commercial vegetable production guides. Corvallis, OR: Oregon State University College of Agricultural Sciences. http://www.orst.edu/Dept/NWREC/vegindex.html

Harrison, H. C., L. G. Bundy, and W. R. Stevenson. 1982. Commercial rhubarb production. University of Wisconsin Cooperative Extension, Publication A2361.

Helsel, D., D. Marshall, and B. Zandstra. 1996. Growing rhubarb. Michigan State University Extension, Home Horticulture Publication 03900106.

http://www.msue.msu.edu/msue/imp/mod03/03900106.html

Ingratta, F. 1979. Growing rhubarb. Toronto: Ontario Ministry of Agriculture and Food, Vegetable Production Recommendations Publication 363.

Nielsen, G. R. 1998. Rhubarb pests. University of Vermont Extension, Entomology Leaflet 79 . http://ctr.uvm.edu/ctr/el/el79.htm

Wohlford, R. and D. Banks. 2000. Rhubarb. University of Illinois Extension. http://www.urbanext.uiuc.edu/veggies/rhubarbl.html 


\section{FOR MORE INFORMATION}

You'll find detailed information on many aspects of vegetable crop production in these UC ANR publications:

Specialty and Minor Crops Handbook, publication 3346

Commercial Cooling of Fruits, Vegetables, and Flowers, publication 21567

Covercrops for California Agriculture, publication 21471

To order these materials, visit our online catalog at http://anrcatalog.ucdavis.edu. You can also place orders by mail, phone, or fax, or request a printed catalog of publications, multimedia, slide sets, and videos from

University of California

Division of Agriculture and Natural Resources

Communication Services

6701 San Pablo Avenue, 2nd Floor

Oakland, California 94608-1239

Telephone: 1-800-994-8849 or (510) 642-2431, Fax: (510) 643-5470

e-mail inquiries: danrcs@ucdavis.edu

An electronic version of this publication is available on the ANR Communication Services website at http://anrcatalog.ucdavis.edu.

Publication 8020

(C) 2000 by the Regents of the University of California,

Division of Agriculture and Natural Resources. All rights reserved.

The University of California prohibits discrimination against or harassment of any person employed by or seeking employment with the University on the basis of race, color, national origin, religion, sex, physical or mental disability, medical condition (cancer-related or genetic characteristics), ancestry, marital status, age, sexual orientation, citizenship, or status as a covered veteran (special disabled veteran, Vietnam-era veteran or any other veteran who served on active duty during a war or in a campaign or expedition for which a campaign badge has been authorized).

University Policy is intended to be consistent with the provisions of applicable State and Federal laws.

Inquiries regarding the University's nondiscrimination policies may be directed to the Affirmative Action/Staff Personnel Services Director, University of California, Agriculture and Natural Resources, 1111 Franklin, 6th Floor, Oakland, CA 94607-5200 (510) 987-0096. For information about downloading this publication, telephone (530) 754-5112.

pr-11/00-GM/WJC

ISBN 978-1-60107-200-9 